\title{
Refractory pharyngeal ulceration due to cytomegalovirus in a patient with HIV infection: a case report and literature review
}

Morichika Osa ${ }^{1}{ }^{2}$, Akihiro Sato ${ }^{1}$, Maki Sakagami ${ }^{1}$, Masaki Machida ${ }^{1}$, Takao Sato ${ }^{1}$, Ayaka Tsukimori ${ }^{1}$, Shinji Fukushima', Itaru Nakamura ${ }^{1 *}$, Ryo Akai ${ }^{3}$, Kiyoaki Tsukahara ${ }^{3}$ and Hidehiro Watanabe ${ }^{1}$

\begin{abstract}
Background: Cytomegalovirus (CMV) is an important pathogen among immunocompromised hosts. Typically, CMV in human immunodeficiency virus (HIV) infection causes diseases of the retina, digestive tract, lungs and liver, but there are few cases of CMV infection of the pharynx and larynx.

Case presentation: A 57-year-old man with HIV infection was admitted because of pharyngeal pain. Before and after admission, pharyngeal biopsies guided by laryngeal endoscopy were performed four times, but pathological examination showed nonspecific inflammation, and the cause of pharyngeal ulceration was unclear. Additionally, the ulceration deteriorated after initiation of retroviral therapy. Laryngomicrosurgery was conducted under general anesthesia to remove tissue, and pathological diagnosis confirmed CMV infection. Pathological features included enlargement of the cytoplasm and nucleus in infected cells, and intranuclear bodies called owl's eye inclusions. Ganciclovir dramatically improved the symptoms and laryngoscopic findings.

Conclusions: This case was diagnosed as pharyngitis and pharyngeal ulceration caused by CMV infection, related to immune reconstitution inflammatory syndrome. In previous reports of CMV-induced pharyngeal or laryngeal ulceration in HIV infection, we found six cases similar to our present case. All cases were diagnosed by biopsy. The present case indicates the importance of biopsy for definitive diagnosis. CMV infection should be considered as a differential diagnosis of pharyngeal ulceration in patients with HIV infection.
\end{abstract}

Keywords: Cytomegalovirus, Pharyngeal ulceration, HIV, Ganciclovir, Case report

\section{Background}

Cytomegalovirus (CMV) is a member of the Herpesviridae that is mainly present in the salivary glands and is not pathogenic in immunocompetent people. However, CMV causes infection in immunocompromised hosts, such as organ transplantation recipients, human

\footnotetext{
* Correspondence: task300@tokyo-med.ac.jp

'Department of Infectious Disease, Tokyo Medical University Hospital, 6-7-1 Nishi-Shinjuku, Shinjuku-ku, Tokyo 160-0023, Japan

Full list of author information is available at the end of the article
}

immunodeficiency virus (HIV)-infected patients, and people treated with immunosuppressive agents (e.g., chemotherapy, steroids). In particular, CMV in patients with HIV infection causes diseases of the retina, digestive tract, lungs and liver [1]. CMV colitis likely causes ulceration as well as inflammation. However, there are few case reports of CMV infection causing ulceration in the pharynx and larynx. We report a case of pharyngeal ulceration caused by CMV in a patient with HIV infection that required five biopsies for diagnosis.

(c) The Author(s). 2021 Open Access This article is licensed under a Creative Commons Attribution 4.0 International License, which permits use, sharing, adaptation, distribution and reproduction in any medium or format, as long as you give appropriate credit to the original author(s) and the source, provide a link to the Creative Commons licence, and indicate if changes were made. The images or other third party material in this article are included in the article's Creative Commons licence, unless indicated otherwise in a credit line to the material. If material is not included in the article's Creative Commons licence and your intended use is not permitted by statutory regulation or exceeds the permitted use, you will need to obtain permission directly from the copyright holder. To view a copy of this licence, visit http://creativecommons.org/licenses/by/4.0/ The Creative Commons Public Domain Dedication waiver (http://creativecommons.org/publicdomain/zero/1.0/) applies to the data made available in this article, unless otherwise stated in a credit line to the data. 
Table 1 Laboratory data on admission

\begin{tabular}{|c|c|c|c|c|c|c|c|c|}
\hline \multicolumn{3}{|c|}{ Peripheral blood } & \multicolumn{3}{|c|}{ Blood chemistry } & \multicolumn{3}{|l|}{ Serology } \\
\hline WBC & 7100 & $/ \mu \mathrm{L}$ & T-Bil & 0.14 & $\mathrm{mg} / \mathrm{dL}$ & CRP & 3.88 & $\mathrm{mg} / \mathrm{dL}$ \\
\hline $\mathrm{Hb}$ & 10.2 & $\mathrm{~g} / \mathrm{dL}$ & AST & 50 & $U / L$ & SIL-2R & 691 & $\mathrm{U} / \mathrm{mL}$ \\
\hline \multirow[t]{6}{*}{ PLT } & $22.9 \times 10^{4}$ & $/ \mu \mathrm{L}$ & ALT & 60 & $U / L$ & RPR & 26.5 & R.U \\
\hline & & & $\mathrm{LDH}$ & 254 & $U / L$ & TPLA & 4187 & T.U \\
\hline & & & $\gamma$-GTP & 74 & $U / L$ & IGRA & $(-)$ & \\
\hline & & & BUN & 33.5 & $\mathrm{mg} / \mathrm{dL}$ & $\mathrm{HBs}-\mathrm{Ag}$ & $(-)$ & \\
\hline & & & $\mathrm{Cr}$ & 1.16 & $\mathrm{mg} / \mathrm{dL}$ & HCV-Ab & $(-)$ & \\
\hline & & & & & & Toxo-lgG & $(-)$ & \\
\hline
\end{tabular}

Abbreviations: ALT alanine aminotransferase, AST aspartate aminotransferase, $B U N$ blood urea nitrogen, $\mathrm{Cr}$ creatinine, $\mathrm{CRP}$ C-reactive protein, $\mathrm{Hb}$ hemoglobin, $H B s-A g$ hepatitis B surface antigen, $H C V-A b$ hepatitis $C$ antibody, IGRA interferon- $\gamma$ release assay, $L D H$ lactate dehydrogenase, $P L T$ platelets, $R P R$ rapid plasma reagin test, $R . U$. RPR units, sIL-2R soluble interleukin-2 receptor, $T$ Bil total bilirubin, Toxo-IgG Toxoplasma IgG, TPLA Treponema pallidum latexagglutination, T.U. titer units, WBC white blood cells

\section{Case presentation}

A 57-year-old Japanese man visited a nearby hospital because of pharyngeal pain. He was diagnosed with Candida pharyngitis and treated with oral amphotericin B. However, because his symptoms did not improve, he was referred to our hospital and scrutinized.

Two months after symptom onset, the patient was afebrile, and physical examination revealed redness of the pharynx. HIV rapid antigen test and polymerase chain reaction were positive, and rapid plasma reagin test (28.8 R.U) and Treponema pallidum latexagglutination test (4476.0 T.U) were also positive. We suspected Candida pharyngitis or Treponema palli$d u m$ infection. Amoxicillin and fluconazole had been administered for 4 weeks and 2 weeks, respectively, but pharyngeal pain deteriorated. Additionally, at the time of presentation, biopsy was performed by an otolaryngologist and there was no evidence of secondary syphilis from the biopsy specimen. Three months after symptom onset, he was admitted to our hospital. On physical examination, the patient was afebrile with a temperature of $36.7{ }^{\circ} \mathrm{C}$, normal blood pressure of $113 / 78 \mathrm{mmHg}$, normal heart rate of 88 beats/min, and normal $\mathrm{SpO}_{2}$ of $97 \%$ (room air). HIV1 viral load and CD4 counts were $3.1^{*} 10^{\wedge} 5 \mathrm{cps} / \mathrm{mL}$ and 11 cells $/ \mu \mathrm{L}$, respectively. Results of other laboratory and imaging studies are shown in Table 1. After admission, the symptoms were resistant to treatment and hoarseness gradually developed. Right arytenoid edema was shown by computed tomography (Fig. 1a, b) and nasopharyngolaryngoscopy (Fig. 2a, b). At this time, blood CMV pp65 antigen was negative. To investigate $\mathrm{CMV}$ infection, polymerase chain reaction (PCR) is the standard for diagnosis. In our case, CMV PCR was not performed because this test was not covered by national health insurance in Japan; therefore, we tested for blood CMV antigen, which is comparable to CMV PCR [2].

An otolaryngologist recommended betamethasone for treatment of laryngeal edema but ulceration and laryngeal edema worsened, and tracheostomy was performed. Blood tests, computed tomography and consultation with an ophthalmologist showed that the patient was negative for active meningeal tuberculosis, cryptococcal meningitis and other opportunistic infections, including CMV infection such as retinitis, gastroenteritis, pneumonitis and hepatitis. Therefore, we started antiretroviral therapy (ART) with abacavir $(600 \mathrm{mg})$, lamivudine (300 $\mathrm{mg})$ and dolutegravir $(50 \mathrm{mg})$, according to the Japanese national protocol. To evaluate the pharyngeal ulceration and edema, biopsies were performed four times after admission. However, the cause of pharyngeal ulceration remained unclear and the symptoms did not improve at all. Three weeks after administration of ART,
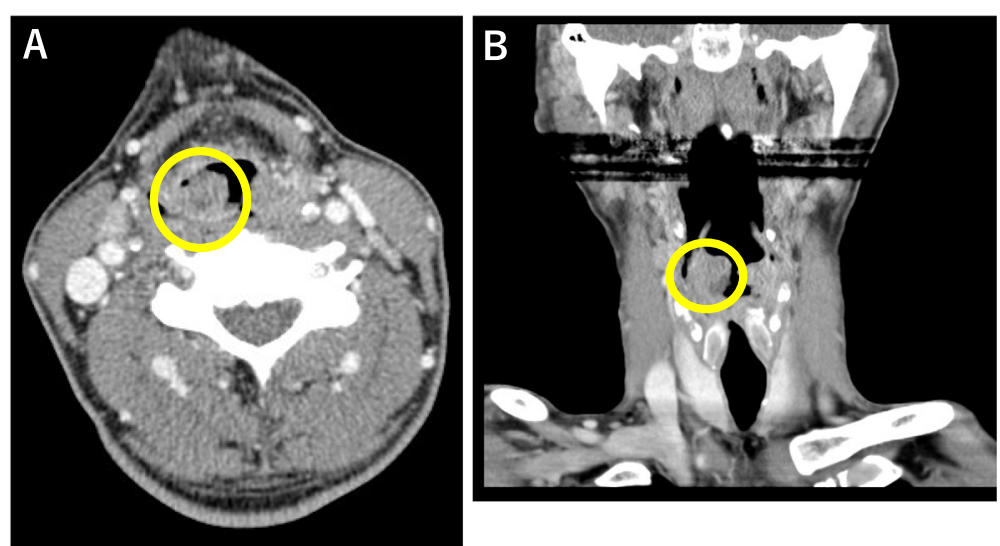

Fig. 1 a: Axial section of head and neck computed tomography. b: Coronal section of head and neck computed tomography. Both images show the right arytenoid edema (yellow circle) 


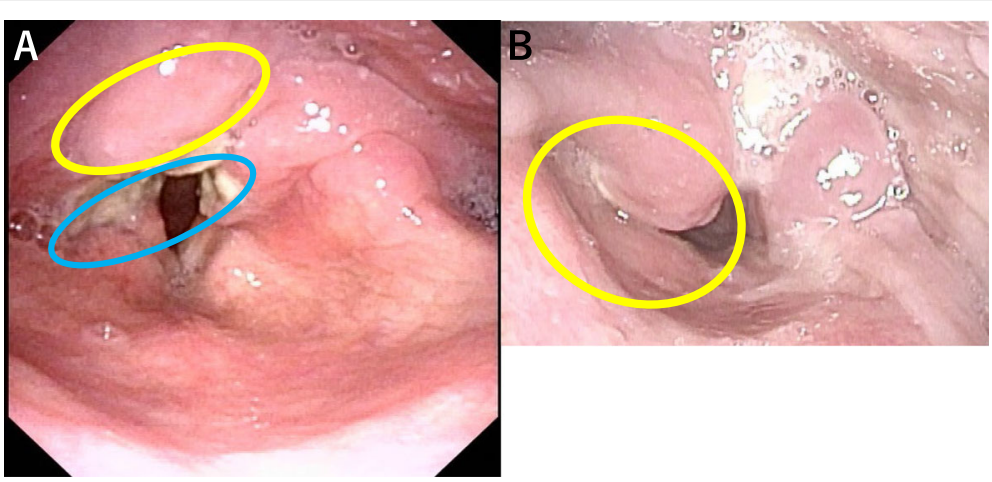

Fig. 2 a: Initial laryngoscopy findings: right arytenoid edema (yellow circle) and pharyngeal ulceration (blue circle). b: Laryngoscopy at admission: right arytenoid edema had deteriorated

CD4 cell count increased to $53 / \mu \mathrm{L}$ and HIV-1 viral load decreased to $5.9^{*} 10^{\wedge} 2 \mathrm{cps} / \mathrm{mL}$.

Additionally, blood CMV pp65 antigen was positive, although it was negative upon admission. CMV can infect the retina, digestive tract, lungs and liver. To investigate these targets of CMV infection, the patient consulted an ophthalmologist and gastroenterologist, and underwent chest X-ray and liver blood tests, respectively. Colonoscopy revealed CMV enteritis, and oral valganciclovir was started. At the same time, tissue biopsy by laryngomicrosurgery was performed under general anesthesia, and we finally found that pharyngeal ulceration was caused by CMV infection (Fig. 3a, b). Therefore, oral valganciclovir was switched to ganciclovir injection. After treatment with ART and ganciclovir, the symptoms dramatically improved. This case was diagnosed as pharyngitis and pharyngeal ulceration caused by CMV infection. Additionally, this case could have been caused by immune reconstitution inflammatory syndrome (IRIS). Because CMV PCR was not performed during the clinical course, it is difficult to confirm whether CMV infection was related to IRIS or newly occurring. One hypothesis is that latent CMV infection caused IRIS after administration of ART.

\section{Discussion and conclusions}

We present the case of an HIV-infected man with CMV pharyngeal ulceration that may have been caused by IRIS. Even though several biopsies were performed, the cause of pharyngeal ulceration was not detected. Eventually, after initiation of ART, CMV pharyngeal ulceration was diagnosed by biopsy under general anesthesia. There were three reasons why the diagnosis was difficult. First, CMV infection was not suspected because C7HRP was negative at the time of admission. Second, the patient had no typical manifestations of CMV infection, such as retinitis, colitis or hepatitis. Third, the amount of collected tissue might have been too small for diagnosis. Also, C7HRP became positive after ART. Therefore, this case was thought to have been caused by IRIS.

Typically, CMV causes infection in the retina, digestive tract, lungs and liver [1]. However, pharyngeal and
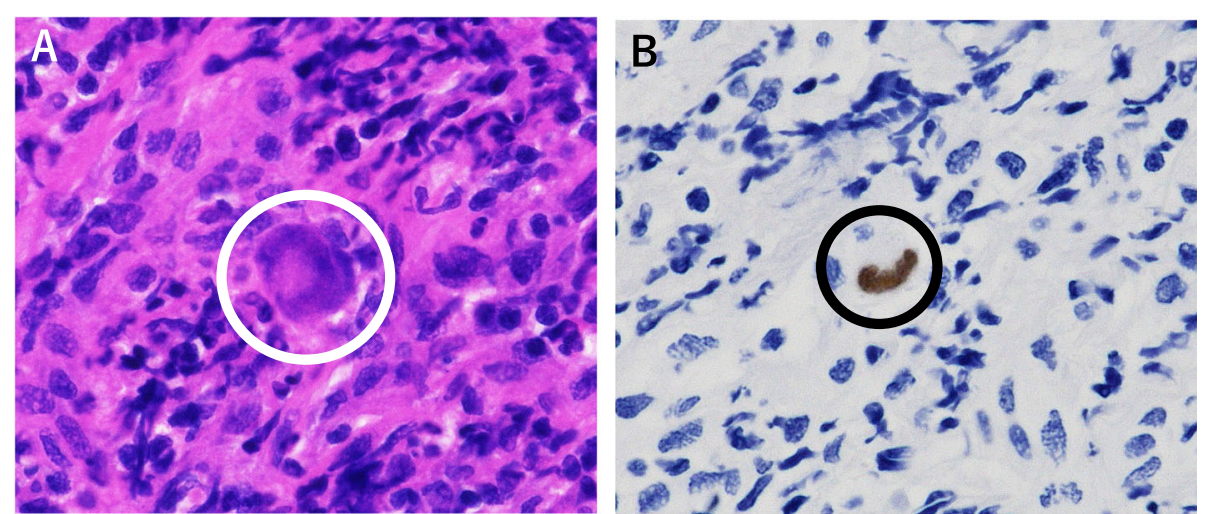

Fig. 3 a: Hematoxylin-eosin: histopathological features of lesion demonstrating enlargement of the cell nucleus (white circle). b: Positive immunostaining for CMV by monoclonal antibody (black circle) 
Table 2 Summary of CMV pharyngeal or laryngeal ulceration with HIV infection in the current and previous cases

\begin{tabular}{|c|c|c|c|c|c|c|c|c|c|c|c|}
\hline No. (Ref) & $\begin{array}{l}\text { Age, } \\
\mathrm{yr}\end{array}$ & Sex & $\begin{array}{l}\text { CD4 cell count } \\
(/ \mu \mathrm{L})\end{array}$ & $\begin{array}{l}\text { HIV RNA } \\
\text { (copies/mL) }\end{array}$ & $\begin{array}{l}\text { CMV DNA or CMV } \\
\text { antigen }\end{array}$ & Site & $\begin{array}{l}\text { No. of } \\
\text { biopsies }\end{array}$ & Treatment & $\begin{array}{l}\text { Treatment } \\
\text { period }\end{array}$ & Outcome & IRIS \\
\hline $1[3]$ & 27 & M & NA & NA & NA & $P$ & 1 & GCV & 2 weeks & Improved & $\mathrm{NA}$ \\
\hline $2[3]$ & 43 & M & NA & NA & NA & L & 2 & GCV & 2 weeks & Improved & NA \\
\hline $3[4]$ & 36 & M & NA & NA & NA & $\mathrm{O}, \mathrm{P}$ & 1 & None & NA & Improved & NA \\
\hline $4[4]$ & 42 & M & NA & NA & NA & $\begin{array}{l}C, D, \\
E, P\end{array}$ & 1 & GCV & 8 weeks & Death & NA \\
\hline $5[4]$ & 45 & M & NA & NA & NA & $\begin{array}{l}\mathrm{D}, \mathrm{L}, \\
\mathrm{O}, \mathrm{P}\end{array}$ & 1 & GCV & NA & Improved & NA \\
\hline $6[5]$ & 33 & $\mathrm{~F}$ & 2 & $5.5^{*} 10 \wedge 5$ & Antigen positive & $P$ & 1 & None & NA & Improved & NA \\
\hline Present & 57 & M & 11 & $3.1 * 10 \wedge 5$ & Antigen positive & $\mathrm{D}, \mathrm{P}$ & 5 & GCV,VGCV & 2 weeks & Improved & + \\
\hline
\end{tabular}

case

$C$ central nervous system, CMV cytomegalovirus, $D$ digestive tract, $E$ eye, $F$ female, GCV ganciclovir, HIV human immunodeficiency virus, IRIS immune reconstitution inflammatory syndrome, $L$ larynx, $M$ male, NA not available, $O$ oral cavity, $P$ pharynx, VGCV valganciclovir

laryngeal ulceration is not typical. Moreover, the present case seems to be rare because it showed CMV pharyngeal ulceration caused by IRIS without CMV retinitis, pneumonitis and hepatitis.

To identify previous cases of CMV pharyngeal or laryngeal ulceration, we searched PubMed using the keywords "Cytomegalovirus", "CMV", "HIV", "Pharyngeal" and "Laryngeal". Additionally, we searched the references of published reports. Seven cases were identified, and they are listed, along with the present case, in Table 2. Two studies were excluded because they did not include enough information for evaluation [6, 7]. The average age of the patients was $40.3 \pm 9.6$ years, six were male, and one had died. CD4 cell count, HIV-1 RNA viral load and CMV DNA or antigen test was available in two cases. In one case, CD4 cell count was $2 / \mathrm{ul}$, HIV-1 RNA viral load was $5.5^{*} 10^{\wedge} 5 / \mathrm{mL}$ and CMV antigen was positive. In our case, CD4 cell count was $11 / \mathrm{uL}$, HIV-1 RNA viral load was $3.1^{*} 10^{\wedge} 5 / \mathrm{mL}$ and CMV antigen was positive. Two cases were not treated and regressed spontaneously, but the others were treated by ganciclovir or valganciclovir. In terms of treatment period, two cases and our case were treated for 2 weeks, one case was treated for 8 weeks. Diagnosis was achieved with one biopsy in five cases and two biopsies in one case. Additionally, it is only our case that describes CMV pharyngeal and laryngeal ulceration caused by IRIS, without typical manifestations such as retinitis, pneumonitis and hepatitis.

Our case required five biopsies for diagnosis. In one of the previous reports, the authors stated that histological diagnosis is vital for diagnosis of oropharyngeal ulcers caused by CMV because these lesions show various microscopic findings [3]. There are many differential diagnoses of pharyngeal ulceration and it is difficult to diagnose. If patients with HIV infection show refractory pharyngeal or laryngeal pain and ulceration, biopsy should be performed. Additionally, this case suggests that CMV IRIS could be the differential diagnosis when refractory pharyngeal or laryngeal ulceration is seen. In conclusion, if a patient has oropharyngeal ulcer with HIV infection, CMV infection should be considered as differential diagnosis.

\section{Abbreviations}

CMV: Cytomegalovirus; HIV: Human immunodeficiency virus; IRIS: Immune reconstitution inflammatory syndrome; PCR: Polymerase chain reaction; RPR: Rapid plasma reagin test

\section{Acknowledgments}

We thank Cathel Kerr, BSc, PhD, from Edanz Group (https://en-authorservices.edanzgroup.com/) for editing a draft of this manuscript.

\section{Authors' contributions}

$\mathrm{MO}$ wrote the initial draft of the manuscript. IN supervised the clinical management and preparation of the manuscript. MO, AS, MS, MM, TS, AT, SF, IN and HW contributed to this case in the treatment and diagnosis during clinical course. Also, RA and KT contributed to this case in the diagnosis. All authors have reviewed the manuscript. All authors approved the final version of the manuscript and agree to be accountable for all aspects of the work in ensuring that questions related to the accuracy or integrity of any part of the work are appropriately investigated and resolved.

\section{Funding}

This research did not receive any specific grant from funding agencies in the public, commercial, or not-for-profit sectors.

\section{Availability of data and materials}

The datasets used and/or analyzed during the current study are available from the corresponding author on reasonable request.

\section{Declarations}

Ethics approval and consent to participate

Not applicable.

\section{Consent for publication}

Written informed consent was obtained from the patient for publication of this case report.

\section{Competing interests}

The authors declare that they have no competing interests.

\section{Author details}

${ }^{1}$ Department of Infectious Disease, Tokyo Medical University Hospital, 6-7-1 Nishi-Shinjuku, Shinjuku-ku, Tokyo 160-0023, Japan. ${ }^{2}$ Division of Infectious Diseases and Respiratory Medicine, Department of Internal Medicine, 
National Defense Medical College Hospital, 3-2 Namiki, Tokorozawa, Saitama 359-8513, Japan. ${ }^{3}$ Department of Otorhinolaryngology-Head and Neck

Surgery, Tokyo Medical University Hospital, 6-7-1 Nishi-Shinjuku, Shinjuku-ku, Tokyo 160-0023, Japan.

Received: 17 April 2020 Accepted: 1 March 2021

Published online: 10 March 2021

\section{References}

1. Springer $\mathrm{KL}$, Weinberg A. Cytomegalovirus infection in the era of HAART: fewer reactivations and more immunity. J Antimicrob Chemother. 2004; 54(3):582-6.

2. Meyer-Koenig U, Weidmann M, Kirste G, Hufert FT. Cytomegalovirus infection in organ-transplant recipients: diagnostic value of pp65 antigen test, qualitative polymerase chain reaction (PCR) and quantitative Taqman PCR. Transplantation. 2004;77(11):1692-8.

3. French PD, Birchall MA, Harris JRW. Cytomegalovirus ulceration of the oropharynx. J Laryngol Otol. 1991;105(9):739-42.

4. Lalwani AK, Snyderman NL. Pharyngeal ulceration in AIDS patients secondary to cytomegalovirus infection. Ann Otol Rhinol Laryngol. 1991; 100(6):484-7.

5. Udagawa H, Yamazaki M, Shiwa M. Cytomegalovirus-associated hypopharyngeal ulcer in a patient with AIDS. Jibiinnkoukatennbo. 2005; 48(6):348-52.

6. Wilcox CM, Straub RF, Clark WS. Prospective evaluation of oropharyngeal findings in human immunodeficiency virus-infected patients with esophageal ulceration. Am J Gastroenterol. 1995;90(11):1938-41.

7. Shagil'dian VI, Tishkevich OA, Parkhomenko IG, Morozova SV, Tishkevich IM, Gruzdev BM, et al. Cytomegalovirus infection of the gastrointestinal tract in patients with HIV-infection. Ter Arkh. 2005;77(11):14-20.

\section{Publisher's Note}

Springer Nature remains neutral with regard to jurisdictional claims in published maps and institutional affiliations.

- fast, convenient online submission

- thorough peer review by experienced researchers in your field

- rapid publication on acceptance

- support for research data, including large and complex data types

- gold Open Access which fosters wider collaboration and increased citations

- maximum visibility for your research: over $100 \mathrm{M}$ website views per year

At BMC, research is always in progress.

Learn more biomedcentral.com/submissions 